\title{
Lithium and the kidney: an update ${ }^{1}$
}

It is a little over a decade since Hestbech et al. (1977) reported histological changes in renal biopsy specimens taken from patients who had been treated with lithium. This prompted a flurry of clinical investigations into functional changes in the kidney related to the long-term use of the ion. During the first five years, the majority of these were cross-sectional (Waller \& George, 1984) but increasing numbers of longitudinal studies, which attempt to define the risks for individual patients, have since been reported. These have focused on the clinically important aspects of renal function affected by lithium, namely glomerular filtration rate and urine concentrating ability. The more recent studies are considered in this review and recommendations for clinical practice are offered.

\section{EFFECT OF LITHIUM ON GLOMERULAR FUNCTION}

If lithium were to affect glomerular function, this would have considerable implications for longterm use. Evidence from early cross-sectional studies indicated that small numbers of patients receiving lithium had glomerular filtration rates (GFRs) below the value expected for an individual of the same age and weight. The major problem in interpreting these observations is the inability to differentiate between an effect of lithium and concurrent renal pathology unrelated to the treatment.

The early studies did not find any trend towards a reduced GFR with prolonged treatment (Waller \& George, 1984) and several recent cross-sectional surveys have found similar results. Jorgensen et al. (1984) demonstrated a moderate reduction in GFR, estimated by ${ }^{51} \mathrm{Cr}$ EDTA clearance, in five of their 54 patients but were unable to find a relationship between the duration of lithium treatment and GFR. Astrug et al. (1985) found a slightly reduced GFR in approximately $30 \%$ of 64 patients, and Hetmar et al. (1986) noted a slight reduction in creatinine clearance in five of their 46 patients but again there were no trends towards a reduction in GFR with prolonged treatment. Gelenberg et al. (1987) reported serum creatinine estimations in 268 patients receiving lithium and also found no trend towards a relationship between a change in renal function and duration of treatment.

Contrasting results were obtained by Løkkegaard et al. (1985), who studied ${ }^{51} \mathrm{Cr}$ EDTA clearance in a group of 153 patients and showed a gradual trend towards a reduced GFR with increasing duration of treatment. However, the regression line did not fall outside the $95 \%$ confidence limits for a healthy control population until after 17 years of treatment. Thus, the authors suggested that a slow decline in GFR could be expected over many years, but that progression to renal failure was unlikely. Support for this view comes from a further cross-sectional study in 32 patients which demonstrated a negative correlation between creatinine clearance and duration of lithium therapy from six months to 12 years (Scherberich et al. 1986).

Reassuringly, data indicating that lithium has little effect on glomerular function have emerged from several longitudinal studies (see Table 1), but their time spans were comparatively short and they therefore cannot exclude an effect resulting from prolonged treatment such as that found by Løkkegaard et al. (1985). Studies using creatinine clearance (Vestergaard \& Amdisen, 1981; Johnson et al. 1984; Amsterdam et al. 1985; DePaulo et al. 1986; Hetmar et al. 1987) or ${ }^{51} \mathrm{Cr}$ EDTA clearance (Jensen \& Rickers, 1984) failed to show any decline in GFR at repeated examinations

\footnotetext{
' Address for correspondence: Dr D. G. Waller, Clinical Pharmacology, Centre Block, Southampton General Hospital, Southampton SO9 $4 \mathrm{XY}$
} 
Table 1. Longitudinal studies of the effects of lithium on glomerular filtration rate

\begin{tabular}{|c|c|c|c|c|c|c|c|}
\hline Authors & $\begin{array}{l}\text { Number } \\
\text { of patients }\end{array}$ & $\begin{array}{c}\text { Mean age at } \\
\text { first test } \\
\text { (years) }\end{array}$ & $\begin{array}{c}\text { Mean plasma/ } \\
\text { lithum } \\
\text { concentration } \\
\text { (mmol/l) }\end{array}$ & $\begin{array}{l}\text { Mean duration } \\
\text { of treatment } \\
\text { at first test } \\
\text { (years) }\end{array}$ & $\begin{array}{l}\text { Mean length } \\
\text { of follow-up } \\
\text { (years) }\end{array}$ & $\begin{array}{l}\text { Mean value } \\
\text { at first test } \\
(\mathrm{ml} / \mathrm{min})\end{array}$ & $\begin{array}{l}\text { Mean change } \\
\text { at follow-up } \\
\text { (ml/min) }\end{array}$ \\
\hline \multicolumn{8}{|l|}{ (1) Creatinine clearance } \\
\hline $\begin{array}{l}\text { Vestergaard \& Amdisen, } \\
1981\end{array}$ & 118 & $42 \cdot 7$ & N/A & $5 \cdot 2$ & 1.7 & 101 & $0^{*}$ \\
\hline Danion et al. 1984 & 11 & 530 & N/A & 0 & 5.0 & 66 & 'no change' \\
\hline Smigan el al. 1984 & 53 & 490 & 0.65 & 0 & $\begin{array}{l}0.3 \\
1.0\end{array}$ & $\begin{array}{l}128 \\
128\end{array}$ & $\begin{array}{l}-22 \\
-13\end{array}$ \\
\hline DePaulo et al. 1986 & 40 & $38 \cdot 0$ & $0-88-096$ & 0 & 11 & 91 & +8 \\
\hline Vaamonde et al. 1986 & 7 & $41 \cdot 0$ & $0.59-079$ & 0.2 & 7.5 & 99 & +6 \\
\hline Hetmar et al 1987 & 32 & N/A & 0.91 & $10 \cdot 0$ & $2 \cdot 0$ & 89 & 0 \\
\hline Waller et al. 1988 & 26 & $47 \cdot 0$ & 0.74 & $4 \cdot 0$ & $4 \cdot 7$ & 105 & +3 \\
\hline \multicolumn{8}{|l|}{$\begin{array}{l}\text { (2) Isotopic or inulin } \\
\text { clearances }\end{array}$} \\
\hline Jensen \& Rickers, 1984 & 13 & $46 \cdot 0$ & $0.6-1 \cdot 2$ & 0 & $1 \cdot 4$ & 102 & -3 \\
\hline Johnson et al. 1984 & 23 & $47 \cdot 5$ & 0.68 & $4 \cdot 7$ & $\begin{array}{l}0.9 \\
19\end{array}$ & $\begin{array}{l}94 \\
94\end{array}$ & $\begin{array}{l}-5 \\
-6\end{array}$ \\
\hline Hetmar et al. 1987 & 26 & N/A & 0.91 & $\mathrm{cl} 00$ & 2.0 & 100 & $-9 \dagger$ \\
\hline
\end{tabular}

* Data have been adjusted to elımınate dıfferences in analytical method between tests.

$+P<005$.

N/A Not available.

carried out after one to two years of continuous treatment with lithium. Three of these studies reported pre-treatment values (Jensen \& Rickers, 1984; Amsterdam et al. 1985; DePaulo et al. 1986) while the others re-examined patients who had already been treated for mean periods ranging from three to 10 years at the time of the first study. One further study undertaken on patients before and after initiating treatment is worthy of mention. Smigan et al. (1984) measured creatinine clearance in 53 patients before, and again four and 12 months after, starting lithium. There was a small fall in GFR at the time of the first follow-up investigation, compared with pre-treatment, but no significant difference between the individual values at four and 12 months.

Creatinine clearances after longer periods of treatment with lithium have been reported by Vaamonde et al. (1986) (seven patients, mean follow-up 7.5 years) and Waller et al. (1988) (26 patients, mean follow-up 4.7 years), while Danion et al. (1984) studied patients who had renal impairment prior to receiving lithium (11 patients, mean follow-up 5 years). In all these reports, GFR was not affected by continued treatment with lithium.

\section{EFFECT OF LITHIUM ON URINE CONCENTRATING ABILITY}

In cross-sectional studies, the most consistent finding in patients receiving long-term treatment with lithium was a reduced maximum urine concentrating ability. Maximum urine osmolality ( $\max$ Uosm) is usually assessed following prolonged water deprivation, administration of arginine vasopressin or a synthetic analogue, or by a combination of the two methods. In all the larger study populations, a lower max Uosm tended to be seen in those patients who had received the largest cumulative dose of lithium or the longest duration of treatment (Waller \& George, 1984).

A number of more recent studies have addressed this question. Some have approached the problem by investigating the factors associated with polyuria, the clinical correlate of a reduced urine concentrating ability. DePaulo et al. (1984) subdivided their patients into two groups: 19 with polyuria $(24 \mathrm{~h}$ urine volume greater than $3 \mathrm{l}$ ) and 77 without. The urine volume and duration of lithium therapy were positively correlated in the 'polyuric' sub-group but not in the non-polyuric group. This suggested to the authors that there may be a sub-group of patients susceptible to lithium-induced polyuria. Astrug et al. (1985) also found a relationship between urine volume and 
Table 2. Longitudinal studies of the effects of lithium on renal tubular function

\begin{tabular}{|c|c|c|c|c|c|c|c|}
\hline Authors & $\begin{array}{l}\text { Number } \\
\text { of patients }\end{array}$ & $\begin{array}{c}\text { Mean age at } \\
\text { first test } \\
\text { (years) }\end{array}$ & $\begin{array}{c}\text { Mean serum/ } \\
\text { lithium } \\
\text { concentration } \\
\text { (mmol/l) }\end{array}$ & $\begin{array}{l}\text { Mean duration } \\
\text { of treatment } \\
\text { at first test } \\
\text { (years) }\end{array}$ & $\begin{array}{l}\text { Mean length } \\
\text { of follow-up } \\
\text { (ears) }\end{array}$ & $\begin{array}{l}\text { Mean value } \\
\text { at first test }\end{array}$ & $\begin{array}{l}\text { Mean change } \\
\text { at follow-up }\end{array}$ \\
\hline (1) $24 \mathrm{~h}$ urine volume & & & & & & $1 / 24 \mathrm{~h}$ & $1 / 24 h$ \\
\hline $\begin{array}{l}\text { Vestergaard \& Amdisen, } \\
1981\end{array}$ & 118 & $42 \cdot 7$ & N/A & $5 \cdot 2$ & $1 \cdot 7$ & $2 \cdot 87$ & $+03^{* *}$ \\
\hline DePaulo el al. 1986 & 40 & $38 \cdot 0$ & $0.88-0.96$ & $2 \cdot 9$ & 1.1 & 234 & $+0.34^{*}$ \\
\hline Hetmar et al 1987 & 32 & N/A & 0.91 & $10 \cdot 0$ & $2 \cdot 0$ & $2 \cdot 84$ & $-0 \cdot 10$ \\
\hline $\begin{array}{l}\text { (2) Maxımum urine } \\
\text { osmolalıty }\end{array}$ & & & & & & mosmol $/ \mathrm{kg}$ & mosmol/kg \\
\hline \multirow{2}{*}{ Johnson et al. 1984} & 23 & 47.5 & 0.68 & $4 \cdot 7$ & 0.9 & 448 & -12 \\
\hline & & & & & 1.9 & 448 & +61 \\
\hline \multirow[t]{2}{*}{ Smigan e't al. 1984} & 53 & $49 \cdot 0$ & 065 & 0 & $0 \cdot 3$ & 801 & -98 \\
\hline & & & & & 1.0 & 801 & -77 \\
\hline Hetmar of al. 1987 & 25 & N/A & 0.91 & cl 0.0 & $2 \cdot 0$ & 688 & +16 \\
\hline Waller et al. 1988 & 26 & 470 & 074 & $4 \cdot 0$ & $4 \cdot 7$ & 713 & $-140^{* *}$ \\
\hline
\end{tabular}

duration of treatment with lithium in their 64 patients, but did not investigate any sub-groups. King et al. (1985) used the expression urine flow per unit of creatine to remove the errors inherent in $24 \mathrm{~h}$ urine collections. They also found a correlation between urine flow and duration of lithium treatment.

More formal assessments of concentrating ability in recent cross-sectional studies have been consistent with earlier reports (Jorgensen et al. 1984; Astrug et al. 1985; Lokkegaard et al. 1985; Gelenberg et al. 1987). Only those studies carried out in relatively small numbers of patients failed to demonstrate an association between reduced max Uosm and duration of treatment (Miller $e t$ al. 1985; Hetmar et al. 1986).

As with glomerular function, more definitive information might be expected to accrue from longitudinal studies (see Table 2). The earliest of these was carried out by Vestergaard and Amdisen (1981), who recorded the $24 \mathrm{~h}$ urine volume in 147 patients who had received lithium for a mean of 5.2 years at the time of their first study. The mean urine volume had increased after an average interval of 1.7 years. Similar results were reported by DePaulo et al. (1986), who studied 38 patients initially after a mean of 2.9 years treatment with lithium and again after an average of a further 1.2 years of continuous treatment. At the second examination there was a significant correlation between duration of lithium treatment and urine volume in the sub-set of eight polyuric patients who had $24 \mathrm{~h}$ urine volumes greater than 31 . These results are, therefore, in keeping with the concept of a susceptible sub-group proposed earlier by the same investigators (DePaulo et al. 1984).

In contrast. Hetmar et al. (1987) were unable to find a change in $24 \mathrm{~h}$ urine volume after two years of follow-up in 32 patients who had received lithium for a mean of 10 years at the initial examination. These investigators also assessed max Uosm after $26 \mathrm{~h}$ water deprivation. The 25 patients thus studied did not show any change in urine concentrating ability, achieving an average of 688 and $704 \mathrm{mOsmol} / \mathrm{kg}$ at the two examinations, a result consistent with the lack of change in the $24 \mathrm{~h}$ urine volumes. Similarly, Johnson et al. (1984) conducted a study in 23 patients, initially after an average of 4.7 years treatment with lithium and again after a mean interval of 1.9 years. The max Uosm after $12 \mathrm{~h}$ water deprivation was low at the time of the first test (mean $448 \mathrm{mOsmol} / \mathrm{kg}$ ) with no significant change (mean $509 \mathrm{mOsmol} / \mathrm{kg}$ ) at the second.

Interesting results came from two other investigations which were carried out initially in patients prior to starting treatment with lithium. Smigan et al. (1984) measured the max Uosm $3 \mathrm{~h}$ after $40 \mu \mathrm{g}$ of intranasal desamino-D-arginine vasopressin (DDAVP). A mean value of $800 \mathrm{mOsmol} / \mathrm{kg}$ fell to $703 \mathrm{mOsmol} / \mathrm{kg}$ after four months' treatment with lithium, but there was no further decline 
by the time the patient had received 12 months' treatment, the mean value then being $723 \mathrm{mOsmol} / \mathrm{kg}$. Amsterdam et al. (1985) also found a reduction in max Uosm (tested by overnight dehydration and subsequent vasopressin) after treatment with lithium for one year. The mean prelithium value of $903 \mathrm{mOsmol} / \mathrm{kg}$ (in 65 patients) fell significantly to $840 \mathrm{mOsm} / \mathrm{kg}$ in the 34 patients re-examined. Seventeen of the patients were studied again after two years, but had no further decline in their max Uosm. Since absolute numbers changed between examination, it is not possible to determine the true size of the mean changes in max Uosm from these data. Results from these last two studies are consistent with potentially reversible effects of lithium on the intracellular events that are triggered in the distal renal tubule after activation of arginine vasopressin receptors (Waller \& George, 1984).

All of the longitudinal studies described above were carried out over short follow-up pr-iods. Thus, any slowly progressive effect of lithium on distal renal tubular function would not be detected after the initial decline in max Uosm. We recently carried out follow-up assessments in 26 patients of $\max$ Uosm during the $8 \mathrm{~h}$ following $2 \mu \mathrm{g}$ intravenous DDAVP (Waller et al. 1988). The patients had received lithium for a mean of 4.0 years at the first test and were studied, again on average 4.7 years later. The max Uosm had declined in all patients from a mean of 713 to $573 \mathrm{mOsmol} / \mathrm{kg}$. After adjusting for the expected decline with increasing age, 23 of the patients showed falls in max Uosm.

\section{THE MECHANISM OF REDUCED URINE CONCENTRATING ABILITY}

This subject was fully reviewed previously (Waller \& George, 1984). Much of the reduction in max Uosm will be reversed if treatment is discontinued. This was demonstrated first by Bucht \& Wahlin (1980) and more recently by Bendz (1985). However, concentrating ability after withdrawal of lithium is below that found in psychiatric patients who have not received lithium (Vestergaard \& Amdisen, 1981; Bendz, 1985), suggesting some permanent residual effects on distal tubular function.

Reduced urine concentrating ability and polyuria are the result of resistance of the kidney tubule to the action of antidiuretic hormone (ADH). During the first few months of treatment this resistance is probably related to the many complex actions of lithium at either the distal tubular ADH receptor, or on intracellular events subsequent to receptor activation (Waller \& George, 1984). The work of Christensen et al. (1985) has confirmed the ability of lithium to inhibit generation of cyclic AMP by isolated rat collecting ducts in response to ADH. Such effects are likely to be reversible when lithium is withdrawn. However, the decline in concentrating ability occurring later in treatment (Waller et al. 1988) cannot be easily explained by these mechanisms. Structural changes have been reported in biopsy specimens from patients receiving lithium. However, many of these have also been found in patients prior to receiving lithium (Waller \& George, 1984). More specific lesions, such as distal tubular vacuolation (Jorgensen et al, 1984), are only present during lithium treatment, but are of unknown functional significance. These, or related changes, may contribute to a delayed decline in tubular function.

\section{DO OTHER DRUGS ACCENTUATE THE TUBULAR NEPHROTOXICITY OF LITHIUM?}

Early studies provided conflicting evidence for a possible synergistic or additive effect of neuroleptics and lithium on max Uosm. In the studies reported by Bucht \& Wahlin (1980) and Gelenberg et al. (1987) the concurrent use of neuroleptics was associated with a lower max Uosm than when lithium was used alone, and similar associations with increased $24 \mathrm{~h}$ urine volume were found by Vesergaard et al. (1979) and Lassen et al. (1986). Waller et al. (1984) demonstrated an independent and possibly synergistic association between the duration of neuroleptic use in lithium treated patients and reduction of max Uosm. A similar interaction was more recently inferred from studies by Aberg-Wistedt et al. (1988). Although the concurrent use of lithium and neuroleptics per 
se did not influence max Uosm in the study by Waller et al. (1984), treatment with neuroleptics in patients who have not received lithium may also be associated with a reduced max Uosm (Waller et al. 1985).

In contrast, other investigators have failed to find a link between the concurrent use of lithium and neuroleptics and impaired distal tubular function (Amsterdam et al. 1985; Lokkegaard et al. 1985). Our recent longitudinal observations in the small number of patients taking both lithium and neuroleptics (Waller et al. 1988) did not reveal a more rapid progression of the concentrating defect than in patients receiving lithium alone. Although there is still some doubt in this area, animal studies provide some reassurance. The combined use of lithium and neuroleptics in rats rendered polyuric by lithium appeared partly to preserve the distal tubular response to arginine vasopressin (Kristensen et al. 1985; Norgaard et al. 1985), a result that is in direct conflict with many of the clinical observations.

\section{OTHER RENAL EFFECTS OF LITHIUM}

Lithium therapy is often associated with minor degrees of proteinuria. This is probably due both to increased glomerular leakage of high molecular weight proteins such as albumin, and reduced tubular reabsorption of others such as $\beta_{2}$-microglobulin (Waller \& George, 1984). The proteinuria rarely reaches clinically important levels, and this is confirmed by more recent observations (Scherberich et al. 1986).

Distal tubular acidosis has also been reported (Waller \& George, 1984) but again is unlikely to be of clinical relevance in most patients.

\section{CONCLUSIONS}

Despite the concern expressed during the late 1970s regarding the effect of lithium on the kidney more recent research, especially longitudinal studies, provides grounds for increasing optimism. The evidence for lithium compromising glomerular function is small, confirming the conclusions of an earlier review (Waller \& George, 1984). There is no evidence that patients are at risk of progressive renal failure and, if a sub-group of more susceptible patients does exist, it is small and should not influence the decision to treat seriously ill patients who might benefit from lithium. Nevertheless, annual estimation of plasma creatinine concentrations should be carried out to detect the occasional patient whose glomerular function may be idiosyncratically impaired by lithium, and the patient who develops a concurrent renal disease that is independent of the use of lithium (see Table 3). Since the excretion of lithium is closely dependent on the glomerular filtration rate, accumulation and toxicity in these patients can be anticipated and thereby avoided.

\section{Table 3. Monitoring of renal function during treatment with lithium}

\section{Before treatment}

(a) Estimate serum creatınine and predict creatinine clearance from serum creatinine using formula

(b) If predicted clearance is less than $70 \mathrm{ml} / \mathrm{min}$ consider measuring glomerular filtration rate using a radiolabelled marker such as ${ }^{31} \mathrm{Cr}$ EDTA or " ${ }^{\mathrm{m}} \mathrm{Tc}$ DTPA.

(c) If GFR $<60 \mathrm{ml} / \mathrm{mm}$ confirmed refer to physician and reconsider usıng lithum. If GFR $<30 \mathrm{ml} / \mathrm{min}$ avoid lithium treatment.

At 12-monthly intervals durung treatment

1.(a) Monitor serum creatinine and predicted creatinine clearance.

(b) If progressive imparment of glomerular function is confirmed, consider stopping lithium.

2.(a) Monitor osmolality of early morning specimen of urine.

(b) If osmolality shows a progressive decline to $<300 \mathrm{mosmol} / \mathrm{kg}$, consider measurement of max Uosm after DDAVP.

(c) If max Uosm after DDAVP does not exceed $300 \mathrm{mosmol} / \mathrm{kg}$ and progressive impairment of tubular function is confirmed, reconsider contınuing treatment with lithum. 
The risk of progressive tubular dysfunction, in particular impaired maximum urine concentrating ability, remains uncertain. An initial, but clinically unimportant, decline is to be expected during the first few months of treatment. This may represent a functional deficit that is largely reversible. The evidence for a more progressive decline in subsequent years is incomplete since most follow-up studies have been carried out over periods of less than two years. Nevertheless, a large body of evidence from cross-sectional studies, combined with that from our recently reported longitudinal study of nearly five years' follow-up, suggests that a progressive reduction of max Uosm is a frequent occurrence. The rate of decline is slow, but after many years it may assume clinical importance, with predisposition to dehydration and consequent acute lithium toxicity. Recent evidence does not support the concept that neuroleptics contribute significantly to this decline in max Uosm. Many of the reported longitudinal studies have followed patients stabilized with plasma levels of lithium at the higher end of the therapeutic range. It remains to be shown whether the use of lower doses in more recent years will reduce the risk of renal tubular impairment. While our conclusions agree fundamentally with those of Schou (1988), one important difference in emphasis emerges. Although lithium does not cause progressive renal failure, ignoring renal function completely will mean that the occasional patient with clinically important disturbance of renal function, perhaps unrelated to lithium use, will be at risk of lithium toxicity. A policy of infrequent biochemical checks should limit such occurrences.

Our earlier recommendations for monitoring renal function during long-term lithium treatment (Waller \& Edwards, 1985) are probably too pessimistic and need revision. In the light of recent evidence, an annual estimation of serum creatinine complemented by estimations of early morning urine osmolality should alert the physician to a decline in renal function in an individual patient (see Table 3).

DEREK G. WALLER AND J. GUY EDWARDS

\section{REFERENCES}

Aberg-Wistedt, A., Elwin, C.-E., Norée, L.-O. \& Wistedt, B. (1988). Lithium and renal function in relation to concomitant therapy. International Clinical Psychopharmacology 3, 277-286.

Amsterdam, J. D., Jorkasky, D., Potter, L. \& Cox, M. (1985). A prospective study of lithium-induced nephropathy: preliminary results. Psychopharmacology Bulletin 21, 81-84.

Astrug, A., Zaimov, K., Vretenarska, M., Mevorakh, E., Kjutchurkova, P., Tzvetanova, E., Dotchev, D. \& Darev, S. (1985). Renal function and enzymatic studies of the urine in patients of a longterm lithium therapy. Przeglad Lekarski 42, 361-363.

Bendz, W. (1985). Kidney function in a selected lithium population. Acta Psychiatrica Scandinavica 72, 451-463.

Bucht, G. \& Wahlin, A. (1980). Renal concentrating capacity in longterm lithium treatment and after withdrawal of lithium. Acta Medica Scandinavica 207, 309-314.

Christensen, S., Kusano, E., Yusufi, A. N. K., Murayama, N. \& Dousa, T. P. (1985). Pathogenesis of nephrogenic diabetes insipidus due to chronic administration of lithium in rats. Journal of Clinical Investigation 75, 1869-1879.

Danion, J. M., Welsch, M. Singer, L., Imbs, J. L. \& Schwartz, J. (1984). Long-term treatment in patients with mild chronic renal insufficiency. $14 \mathrm{~h}$ Collegum Internatıonale Neuro-Psychopharmacologicum Congress 1984, Abstract F183.

DePaulo, J. R. Jr, Correa, E. I. \& Sapır, D. G. (1984). The pattern of polyuria in relation to duration of lithium treatment. Biological Psychairy 19, 1345-1349.

DePaulo, J. R., Correa. E. I. \& Sapir, D. G. (1986). Renal function and lithium: a longitudinal study. American Journal of Psychiary 143, 892-895.

Gelenberg, A. J., Wojcik, J. D., Falk, W. E, Coggins, C. H., Brotman, A. W., Rosenbaum, J. F., LaBrie, R. A. \& Kerman, B. J. (1987), Effects of lithıum on the kidney. Acta Psychiatrica Scandinavica 75, 29-34.
Hestbech, J., Hansen, H. E., Amdisen, A. \& Olsen, S. (1977). Chronic renal lesions following long-term treatment with lithium. Kidney International 12, 205-213.

Hetmar, O., Bolwig, T. G., Brun, C., Ladefoged, J., Larsen, S. \& Rafaelson, O. J. (1986). Lithium: long-term effects on the kidney. I. Renal function in retrospect. Acta Psychiatrica Scandinavica 73, $574-581$.

Hetmar, O., Clemmesen, L., Ladefoged, J. \& Rafaelson, O. J. (1987). Lithium: long-term effects on the kidney. III. Prospective study. Acta Psychiatrica Scandinavica 75, 251- 258.

Jensen, S. B. \& Rickers, H. (1984). Glomerular filtration rate during lithium therapy. Acta Psychiatrica Scandinavica 70, 235-238.

Johnson, G. F. S., Hunt, G. E., Duggin, G. G., Horvath, J. S. \& Tiller, D. J. (1984) Renal function and lithum treatment: inttial and follow-up tests in manic-depressive illness. Journal of Affective Disorders 6, 249-263.

Jorgensen, F., Larsen, S., Spanager, B., Clausen, E., Tango, M., Brunch, E \& Brun, C. (1984). Kidney function and quantitative histological changes in patients on long-term lithıum therapy. Acta Psychiatrica Scandinavica 70, 455462.

King, J. R., Aylard, P. R. \& Hullin, R. P. (1985). Side-effects of lithium at lower therapeutic levels: the significance of thirst. Psychological Medicine 15, 355-361.

Kristensen, A. R., Hannmer, M. \& Christensen, S. (1985). Chlorpromazine increases the lowered response to antidiuretic hormone in rats with lithıum-induced diabetes insıpidus. Acta Pharmacologica et Toxicologica 56, 63-68.

Lassen, E., Vestergaard, P. \& Thomsen, K. (1986) Renal function of patients in long-term treatment with lithium citrate alone or in combination with neuroleptics and antidepressant drugs. Archives of General Psychiatry 43, 481-482.

Lokkegaard, H., Andersen, N. F., Henriksen, E., Bartels, P. D., Brahm, M., Baastrup, P. C., Jorgensen, H. E., Larsen, M., Murck, O., Rasmussen, K. \& Schroder, H. (1985). Renal function in 153 manic-depressive patients treated with lithium for more than five years. Acta Psychiatrica Scandinavica 71, 347755. 
Miller. A L. Bowden. C L. \& Plewes, J (1985). Lithium and imparment of renal concentrating ability. Journal of Affective Disorders 9. 115-119.

Norgaard, J., Faarup, P., Hansen, B. B., Kristensen, A R. \& Christensen, S. (1985). Correlation between distal nephron enzyme actovity, structure and function in rats during lithium and lithium plus neuroleptic treatment. Renal Physiology 8, 50-61.

Scherberıch. J. E.. Demisch, K., Wehrheim, C, Rosskopf, H., Bauer, $J$ \& Schoeppe, W. (1986). Effect of lithium on kidney function, serum proteinuria and excretion of tubular membrane proteins in psychuatric patients. Kudney International 26, 1255-1256.

Schou, M. (1988). Effects of long-term lithium treatment on kidney function : an overview. Journal of Psychatric Research 22. 287-296.

Smıgan, L., Bucht, G., von Knorring, L., Perris, C. \& Wahlın, A (1984). Long-term lithium treatment and renal functions $A$ prospective study. Neuropsychobiology 11, 33-38.

Vaamonde. C A.. Milıan, N. E., Magnnat, G. S., Perez, G. O. \& Oster, J. R (1986) Longitudinal evaluation of glomerular filtration rate during long-term lithium therapy American Journal of Kidney Diseaser 7, 213-216.
Vestergaard, P. \& Amdisen, A. (1981). Lithıum treatment and kidney function: a follow-up study of 237 patients on long-term treatment. Acta Psychiatrica Scandinavica 63, 333-345.

Vestergaard, P. \& Hansen, H. E. (1979). Assessment of renal concentrating ability in lithium-treated patients. Acta Psychiatrica Scandmavica 61, 152-156.

Waller, D. G. \& Edwards, J. G. (1985). Investigating renal function during lithium treatment. Psychological Medicme 15, 369-375.

Waller, D. G. \& George, C. F. (1984). Lithium and the kidney. Adverse Drug Reactions and Acute Poisoning Reviews 3, 65-89.

Waller, D. G., Edwards, J. G. \& Papasthatis-Papayann, S. (1988). A longitudinal study of renal function during treatment with lithium. Quarterly Journal of Medicine 255, 553-558.

Waller, D. G., Edwards, J. G. \& Polak, A. (1985). Neuroleptics, lithium and renal function. British Journal of Psychtatry 146 $510-514$.

Waller, D. G., Edwards, J. G., Naik, R. \& Polak, A. (1984), Lithium and renal function. Quarterly. Journal of Medicine 211, 369-379. 